Draft Executive Summary for the Governor's Upper Yellowstone River Task Force 25 February 2003

\title{
Effects of Channel Modification on Fish Habitat in the Upper Yellowstone River
}

\author{
Zachary H. Bowen, Ken D. Bovee, Terry J. Waddle \\ U.S. Geological Survey \\ Fort Collins Science Center \\ 2150 Centre Avenue, Building C \\ Fort Collins, Colorado 80526-8118
}

\section{Introduction}

During the last several decades, portions of the upper Yellowstone River have been modified for flood control and erosion prevention. The U. S. Army Corps of Engineers (USACE) is responsible for administration of a permit program for evaluating construction activities affecting rivers, streams and wetlands. Following two consecutive large floods during 1996 and 1997, the number of permit applications received by the USACE for channel modification structures increased. In response to concern regarding the potential environmental and ecological consequences of channel modification, the USACE and the Governor's Upper Yellowstone River Task Force, in conjunction with state and local government agencies, initiated a cumulative effects investigation to better understand the effects of channel modification in the upper Yellowstone River. Results from the cumulative effects investigation will support more informed decisions about river management and serve as a foundation for future monitoring and research. This report is a summary of research findings from the fish habitat study that was conducted as part of the cumulative effects investigation.

The goal of the fish habitat study was to evaluate the effects of channel modification on shallow depth, slow current velocity (SSCV) habitat. We focused on SSCV habitat because poor recruitment arising from a lack of SSCV habitat is a limiting factor for many fish species, including salmonids. SSCV habitat (with varying quantitative definitions in different studies) has been demonstrated repeatedly as an important growth and survival factor for young fish. The larvae and early juvenile lifestages of virtually all species share the common characteristics of small size, poor swimming capability, and reliance on zooplankton, small insects, and detritus as primary food items. Shallow water, slow current velocity habitats found in backwaters and side channels provide refuge from high current velocities in main channel areas that can displace small fish downstream, especially during periods of high discharge. These SSCV habitat areas typically provide favorable feeding conditions and shallow water in combination with structural cover can reduce the risk of predation for small fish.

Our study examined the effects of bank armoring and flow training structures on the availability of SSCV habitat. We mapped representative sites in the upper Yellowstone River and used hydrodynamic models and hydrograph data to describe the availability of SSCV habitat during different hydroperiods. We focused on availability of SSCV habitat because of its function as a refugium and nursery habitat for young fishes that were sampled as part of the fish population study. Our study was designed in 
conjunction with the fish population study to address important questions regarding channel modification and habitat for juvenile fish. Specifically, the questions we addressed were:

1. Do different levels of channel modification change the amount or distribution of SSCV habitat at different sites?

2. Does availability of SSCV habitat vary among sections of river with different types of modified and unmodified banks?

3. How important is large woody debris in creating SSCV habitat?

4. What is the relative importance of main channel SSCV habitats compared to SSCV habitat available in side channels and other areas?

\section{Study Area}

Habitat mapping and modeling work was conducted in three reaches that were selected to: (1) represent the geomorphic setting where channel modification occurred or was likely to occur; (2) include different levels of intensity of channel modification; and (3) coincide with study reaches sampled during the fish population study. Reach one (named AA) started just downstream from Mallard's Rest Fishing Access and ended about $300 \mathrm{ft}$ upstream from the Pine Creek Bridge (river miles 513.4 to 510.8). Reach two (Tecca) started downstream from Pine Creek Bridge and ended upstream from the confluence of Nelson's Spring Creek (river miles 509.2 to 506.6). Reach three (Livingston, LVG) extended from just above Siebeck- $9^{\text {th }}$ Street Island to the Highway 89 bridge (river miles 500.8 to 496.9 ).

\section{Methods}

Study approach

As a general procedure, we used a two-dimensional hydrodynamic simulation model and a geographic information system (GIS) to generate habitat classification maps of each site for flows typical during base flow (1,500 cfs), snowmelt runoff $(24,000 \mathrm{cfs})$, and recession (5,000 cfs). Each site was subdivided into bank types following the conventions used in the fish population study (e.g., straight, outside bend, point bar, riprap). We used output from the hydrodynamic model and the bank type map in the GIS to determine the amount and distribution of SSCV habitat $(<3$ feet deep, $<1.5$ $\mathrm{ft}$ per second velocity) among modified and unmodified river sections.

\section{Data collection}

Input to the two-dimensional hydrodynamic model consisted of a topographic $(\mathrm{x}, \mathrm{y}, \mathrm{z})$ description of the study site, a roughness parameter for each $\mathrm{x}, \mathrm{y}$ location, inflow discharge, and downstream (exiting cross section) water surface elevation. Topographic data for floodplains, permanent islands, and other above-water features were obtained from aerial photogrammetry and global positioning system (GPS) ground surveys. Echosounding and ground surveys were used to obtain topographic data for the underwater channel bed. All data were projected as Montana State Plane coordinates, 
referenced to the National Geodetic Survey benchmark (designation AERO, PID QX0005) located at the Livingston Airport. Referencing site benchmarks to the benchmark at the airport provides a common reference for future surveys in the event that local benchmarks were lost. Linear units are in feet, areas in square feet or acres, and volumes in cubic feet.

Contractors conducted the photogrammetric analysis using 1:12,000,1:8000 and 1:6000 scale photography. Survey-grade GPS receivers were used to obtain calibration data for the photogrammetric analysis. In addition, we surveyed the tops and toes of banks and the perimeters and surfaces of islands, bars, and man-made structures to ground-truth and supplement the photogrammetry data.

Bathymetric and current velocity data were collected using a boat-mounted echo sounder and acoustic doppler current profiler (ADCP) in conjunction with a surveygrade GPS receiver. Channel features such as margins, bars, islands, and secondary channels were traced with the echo sounder. Additional data were collected longitudinally along traces spaced 30-60 feet apart between the channel feature traces. Where the water was too shallow for echosounding ( $<$ one foot deep), we collected ground survey data using GPS. Water surface elevations and positions were measured at intervals of 600-1000 feet along the channel to generate a profile of the water surface throughout each study site. Discharge was obtained from the USGS gage at Livingston, MT.

\section{Flow simulation}

The River-2D two-dimensional (depth-averaged) hydrodynamic model developed at the University of Alberta was used to simulate depths and water velocities at unmeasured flows. We chose this model because it works in steep rivers and has a history of performing well in complex channels.

For calibration, we provided boundary conditions of inflow discharge and the measured water surface elevation at the outflow. Calibration was achieved by scaling the roughness values for different parts of each study site. Our primary criterion for calibration was matching of the predicted and measured water surface profiles for the site. In general, this criterion was satisfied if the predicted water surface elevations were \pm 4 inches/mile of the measured values.

Simulation runs required boundary conditions (inflow discharge and outflow water surface elevation) from stage-discharge relations that were developed on-site. A file containing location (coordinates), predicted depth, and predicted velocity at each node in the hydrodynamic model was created at the completion of each simulation for input to habitat mapping and spatial analysis programs.

\section{Habitat Mapping}

The Arc/Info Geographic Information System was used to construct grid maps from the files generated by the flow simulations. These grids were reclassified into categories of depth and velocity and then combined to create maps of depth-velocity classes. We generated habitat maps representing typical base flow, runoff, and recession discharges (1,500 to 24,000 cfs) for the three study sites.

Additional map layers were created by hand digitizing directly from the aerial photographs. Large woody debris (LWD), defined as logs greater than one foot in 
diameter, was identified and mapped at each site. Separate map layers were developed for small stems ( $<1.5 \mathrm{ft}$ diameter), large stems $(>1.5 \mathrm{ft}$ diameter), root wads, willow thickets, and dense brush. A ten-foot buffer (five-foot for small stems) was drawn around each woody feature to represent the distance at which the feature no longer influenced the current velocity. A gradient of drag coefficients was then interpolated between the woody feature (maximum drag) to the edge of the buffer (no drag). Grids of bare-ground velocities (output from the hydrodynamic model not accounting for effects of LWD) and the drag coefficients were multiplied to create LWD-moderated grid maps. In this manner, velocities in the vicinity of log jams, snags, and brush piles were reduced locally, whereas all other velocities were the same as in the bare-ground model. By calculating the amount of SSCV habitat predicted for the LWD-moderated and bare-ground models, respectively, it was possible to determine the contribution of LWD to the total amount of SSCV habitat.

Each site was also divided into bank types that were based on the conventions used in the fish population study. Bank types were inside bend, straight, outside bend, riprap, jetty, barb, side channel, point bar, and overbank. Channel modification structures were delineated based on data from the 1999 physical features inventory, the 2001-2002 fish population study, and our survey of structures conducted during 2001. For main channel areas, a centerline was used to distinguish the features from the top of the bank to the middle of the channel. Although this convention tended to exaggerate the area of stream actually containing the physical material of riprap, jetties, or barbs, it was a consistent and objective method for classifying entire reaches of river.

The depth-velocity classification maps were used to calculate the total area of SSCV habitat for several flows at each site. This allowed us to compare availability of SSCV habitat between sites with different levels of channel modification. By overlaying the depth-velocity classification maps with the bank type polygon map, we were able to determine how SSCV habitat was distributed among the various bank types at different flows. This analysis was done to evaluate differences in SSCV habitat availability among bank types and to assess the importance of side channels as potential habitat and refugia for juvenile fish. Finally, we determined the contribution of LWD to area of SSCV habitat over a range of flows at each site. To facilitate comparisons among sites with unequal lengths, we normalized all habitat values by dividing areas by valley lengths.

\section{Results and Discussion}

1. Do different levels of channel modification change the amount or distribution of SSCV habitat at different sites?

At bankfull discharge, the Livingston site had the largest percentage of withinbank areas classified as modified (containing riprap, barbs, or jetties; 20\%) and the smallest area of SSCV habitat per mile of the three study reaches (Figure 1.). The percentages of area modified at AA $(10 \%)$ and Tecca $(9 \%)$ were about half the percentage modified at the Livingston site while areas of SSCV habitat per mile were 1.7 and 2.6 times larger at AA and Tecca, respectively. 


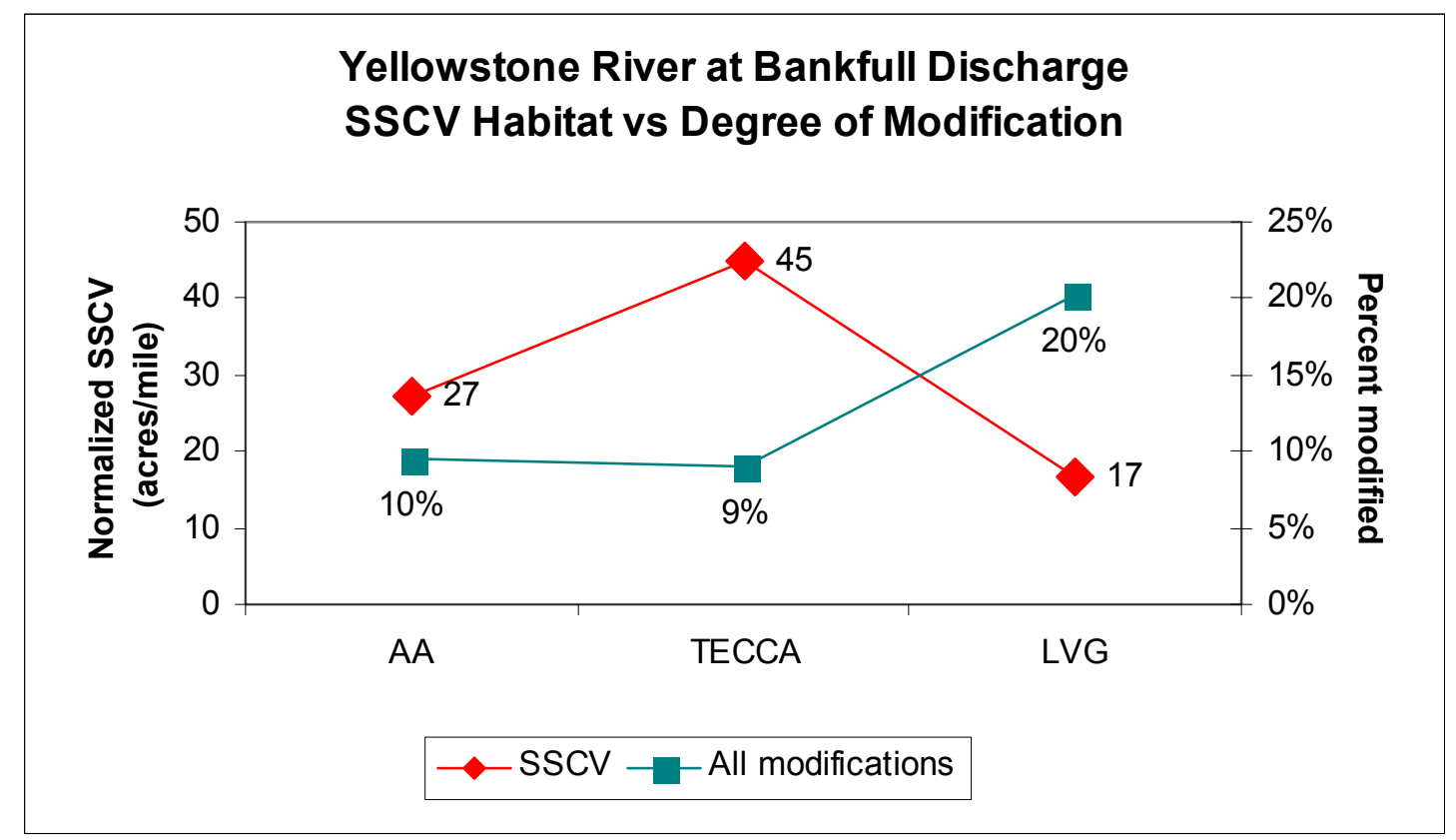

Figure 1. Area of SSCV habitat per mile (diamonds) and percentage of within-bank area with channel modification (squares) at bankfull discharge for three sites in the Upper Yellowstone River near Livingston, MT.

The comparatively lower value for SSCV habitat per mile at the Livingston site is attributable to reduced SSCV habitat availability in side channels and overbank areas. Although the channel near Livingston is classified as wandering gravel bed, the channel is generally more confined than at the other two study reaches. On the east side of the valley near Livingston, flooding, channel migration, and side channel formation are constrained by a resistant high elevation valley wall. To the west, riprap and levees installed to prevent erosion and flooding in the town of Livingston similarly reduce the area of overbank inundated and limit the availability of SSCV habitat in side channels.

Areas with the least amount of SSCV habitat within the Livingston site occurred where the channel was confined and energy was highest (e.g., from the $9^{\text {th }}$ Street Bridge to Mayor's Landing Fishing Access). Future channel modification that similarly constrained the river channel or limited side channel development and inundation would likely result in high energy hydraulic conditions and reduced area of SSCV habitat.

2. Does availability of SSCV habitat vary among sections of river with different types of altered and unaltered banks?

Shallow, slow current velocity habitat was not evenly distributed among bank types at base flow (Figure 2.) Most SSCV habitat was associated with main channel areas with some occurring in side channels. Comparison of modified and unmodified areas showed there was as much or more SSCV habitat associated with unmodified main channel areas as with modified areas (Figure 2.). Results from the fish population study showed equal or higher abundances of juvenile salmonids in modified main channel habitats compared to unmodified main channel habitats. A strong conclusion from the 
fish population study was that during base flow, river banks containing boulders were used by juvenile salmonids. Higher abundances of juvenile trout in modified areas, where overall availability of SSCV habitat was lower than in unmodified areas, suggest that visual isolation (e.g., predator avoidance) is more important than hydraulic shelter during late summer and at lower discharges. This finding supports conclusions from the fish population study that boulders were contributing habitat diversity and refuge along main channel banks that attracted juvenile trout. Other studies have found that juvenile trout move into deeper, faster areas as they grow and their diet changes from zooplankton to insects.

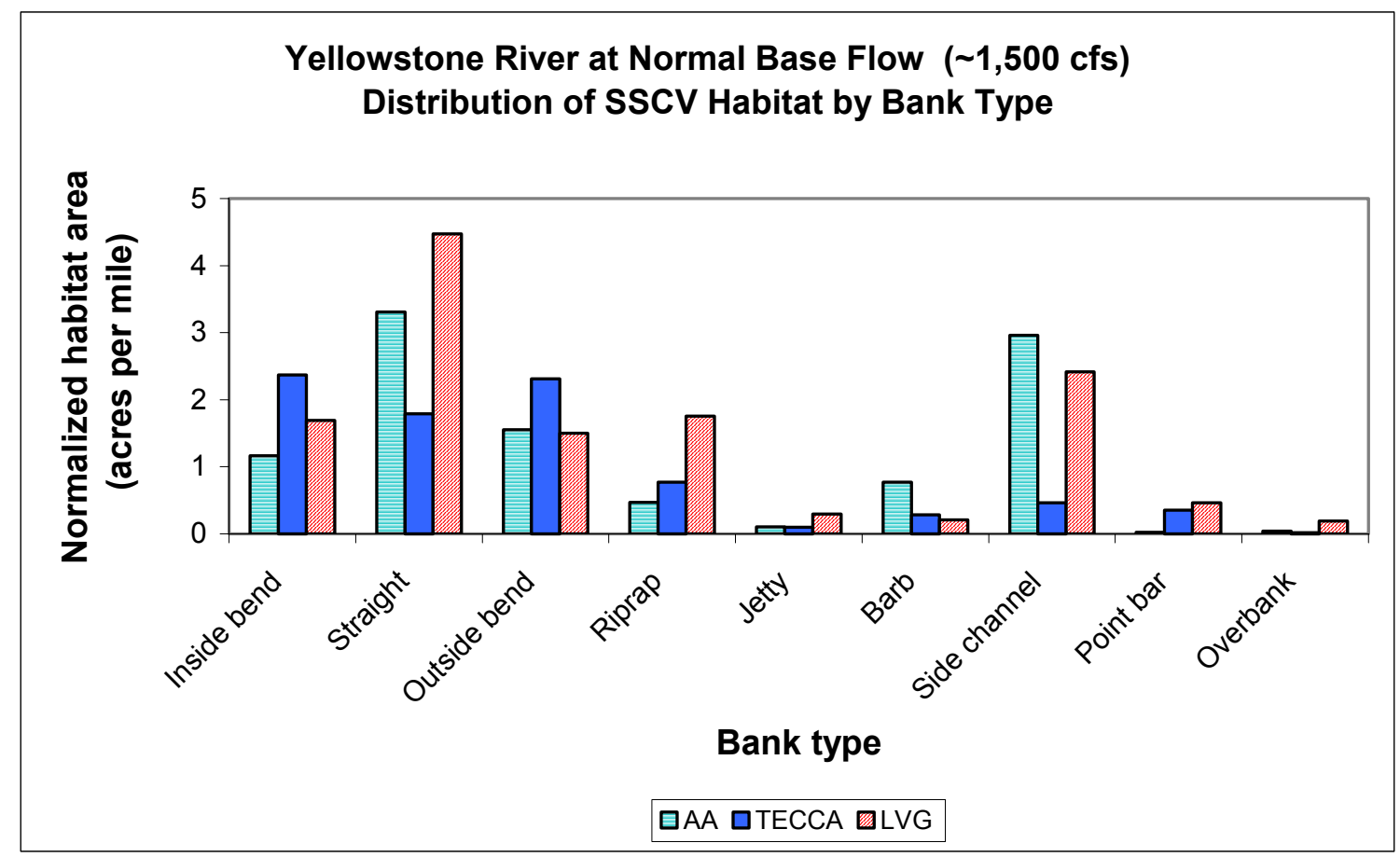

Figure 2. Distribution of SSCV habitat by bank type at a typical base flow discharge $(1,500 \mathrm{cfs})$ for three sites in the Upper Yellowstone River near Livingston, MT.

3. How important is large woody debris in creating SSCV habitat?

Large woody debris and willow thickets created a larger proportion of SSCV habitat at Livingston than at either AA or Tecca (Figure 4.). At bankfull discharge, retardation of velocities by LWD accounted for about $10 \%$ of the SSCV habitat occurring at the upstream sites, but nearly $25 \%$ of the SSCV habitat at Livingston. However, the density of LWD was about $60 \%$ higher at AA, and about 3.5 times higher at Tecca, respectively, than at Livingston. Several factors may have contributed to the larger contribution of SSCV by LWD at Livingston. First, the spatial distribution of LWD was different among the sites. At AA and Tecca, large amounts of LWD occurred in overbank areas and point bars at relatively high elevations compared to the bankfull stage. From the aerial photographs, most of the wood at AA and Tecca appeared to have 
been deposited at flows much higher than bankfull (i.e., during the 1997 event) or felled at higher elevations by beavers. At Livingston, accumulations of LWD occurred at lower elevations where they could be more readily inundated by discharges near bankfull. Second, much of the LWD at AA and Tecca occurred in areas where the bare-ground velocity was already low. When inundated, LWD in these areas would not have retarded velocities significantly, compared to LWD in the higher-energy locations at Livingston. Third, very large areas of SSCV were associated with side channels and overbank locations at AA and Tecca. Although LWD contributed comparable areas of SSCV at these sites, the proportional contributions were smaller. Channel modifications that result in decreased cottonwood recruitment would also decrease availability of LWD habitat for juvenile fish.

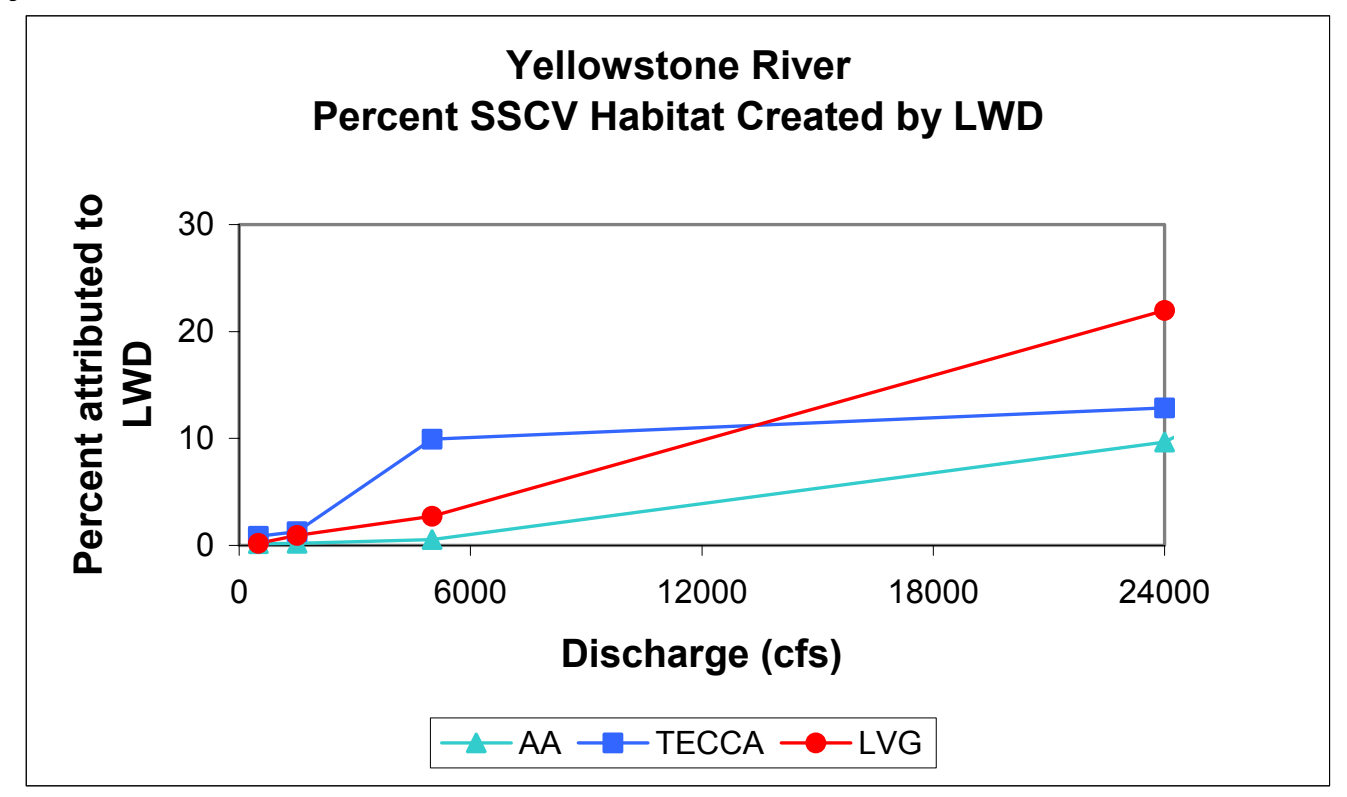

Figure 3. Percentage of SSCV habitat attributable to large woody debris at different discharges for three sites in the Upper Yellowstone River near Livingston, MT.

4. What is the relative importance of main channel SSCV habitats compared to SSCV habitat available in side channels and other areas?

At bankfull discharge, main channel areas contributed negligible amounts of SSCV habitat at all three sites, compared to side channel and overbank areas (Figure 3.). Side channels and overbank areas provided $86.6 \%$ of the SSCV habitat at AA, $84.5 \%$ at Tecca, and $79.9 \%$ at Livingston. During a typical runoff discharge, main channel areas were dominated by high water velocities and large depths compared to overbank and side channel areas. These results highlight the importance of side channels and overbank as areas of SSCV habitat, particularly at higher discharges when the probability of downstream displacement for juvenile fish in main channel habitats is highest.

The most critical time period for young of year fish is from emergence through the runoff period. Because of small size and poor swimming capability, young of year fish are subject to downstream displacement during runoff unless they occupy areas with slow current velocity. Shallow, slow current velocity habitats are required as refugia and 
nursery areas for fry and younger age classes of fish in many systems. This generalization is supported by studies in small, warmwater streams, coldwater streams, and great floodplain rivers. This finding is also consistent with results from the fish population study that showed juvenile fish occupied ephemeral side channels as soon as they became inundated and that juvenile abundances increased with duration of side channel inundation.

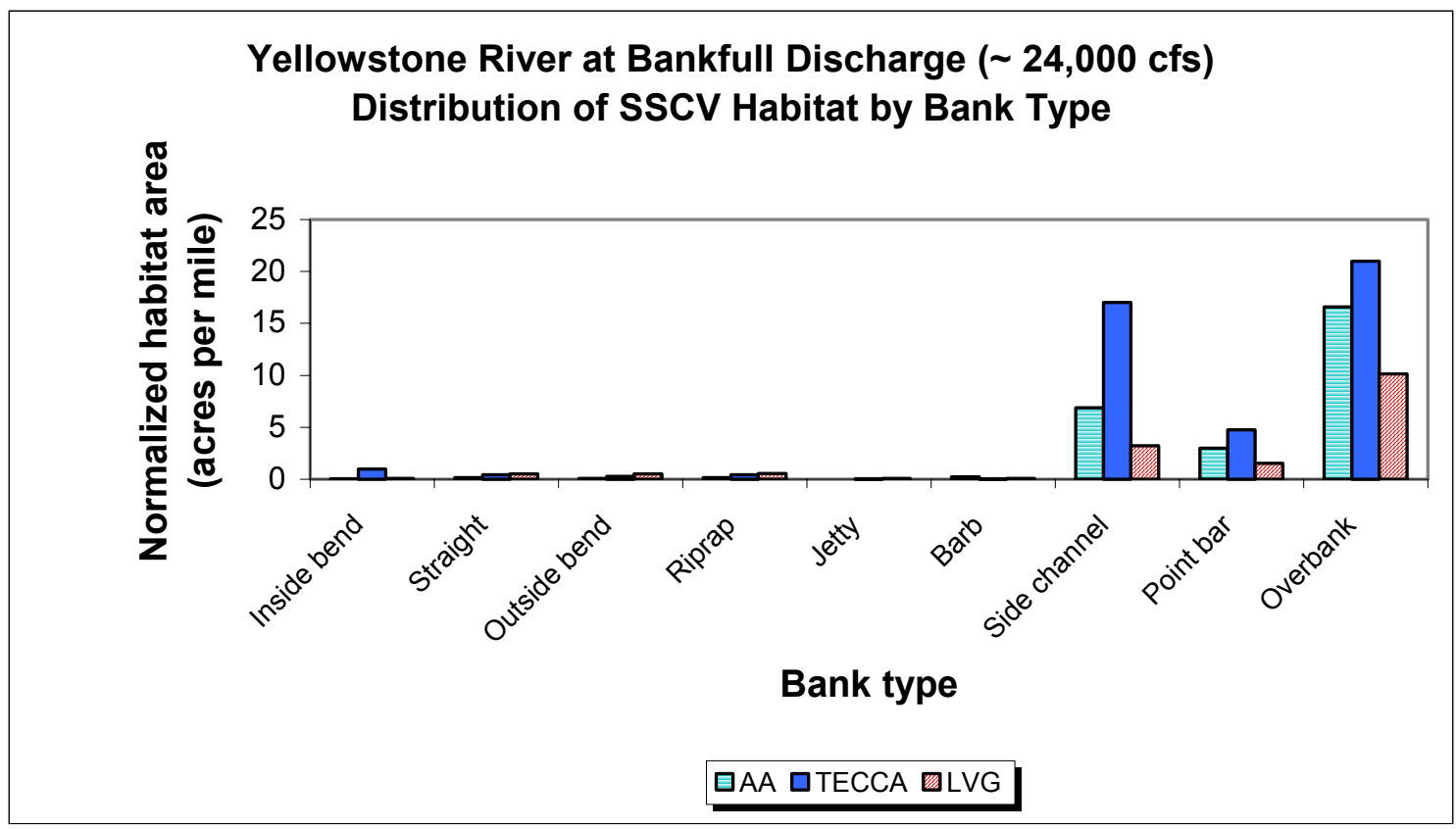

Figure 4. Distribution of SSCV habitat by bank type class at a typical bankfull discharge $(24,000 \mathrm{cfs})$ for three sites in the Upper Yellowstone River near Livingston, MT.

The combined results from the fish population and fish habitat studies present strong evidence that during runoff, SSCV habitat is most abundant in side channel and overbank areas and that juvenile salmonids use these habitats as refugia. Channel modifications that result in reduced availability of side channel and overbank habitats, especially during runoff, will probably cause local reductions in juvenile abundances during the runoff period. The effect of local reductions during runoff on adult numbers later in the year will depend on the extent of channel modification, patterns of fish displacement and movement, and longitudinal connectivity between reaches that contain refugia and those that do not.

\section{Glossary}

Acoustic doppler current profiler (ADCP) - a device that measures water velocity and flow direction using sound waves. 
Bankfull - discharge where the water surface elevation is nearly equal to the top of the main channel banks. In the reaches studied bankfull discharge equals about $24,000 \mathrm{cfs}$.

Base flow - period of stable low flow after runoff and recession that usually occurs during late summer through winter.

Calibration - process of adjusting parameters in a model until model-predicted values (in this case, water surface elevation and relative velocities) match or are close to measured values.

Drag coefficient - a multiplier used to achieve a percentage reduction in velocity that varied linearly from the center of a large woody debris object ( $100 \%$ reduction) to the edge of the field of influence ( $0 \%$ reduction).

Echosounder - a device that measures water depth from a boat using sound waves. The scientific echosounder used in this study is capable of \pm one inch precision.

Geographic Information system (GIS) - computer software used to create and analyze map-based data sets.

Global positioning system (GPS) - system of satellites and ground control stations that allows precise determination of positions and elevations by receivers used in mapping and surveying. The survey-grade equipment used in this study is capable of \pm one to three inch precision, horizontally and vertically.

Grid maps - a type of data set where values (e.g., depths) are represented as individual squares (called cells) of fixed size that together make up a grid representing the map area.

Hand digitizing - creation of a GIS map layer by tracing and identifying features from digital photographs (or other source data) on a computer screen.

Hydrodynamic model - a model that calculates a balance of forces and mass flow to predict water surface elevations, depths, and velocities.

Hydroperiod - a portion of the hydrograph characterized by the period of time the hydrograph reflects a particular pattern of precipitation and runoff. For example, base flow is primarily associated with groundwater, has little surface runoff component, and typically occurs from October to January in the Rocky Mountain region

Map layers - also called coverages. These are map-based data that contain information on a certain topic. For example, one map layer could show depths while a second layer could show locations of large woody debris.

Overbank - the area above the typical channel bank that is inundated by flows greater than the bankfull discharge. In this study, vegetated islands and bars were also classified 
as overbank, even though they might be inundated at bankfull discharge or somewhat less.

Recession - period during which discharges decrease from peak flow during runoff to base flow during late summer or fall.

Recruitment - the supply of fish that becomes available at a certain size or lifestage. For example, a fish might be considered a recruit when it reaches catchable size or when it reaches sexual maturity.

Roughness parameter - a value representing the average height of roughness elements, generally meaning the substrate on the river bottom, that is used to calibrate the hydrodynamic model.

Runoff - In the western U.S. , the hydroperiod associated with snowmelt, resulting in the annual rise in discharge during May and June, followed by the recession from peak flow to base flow.

Simulation - use of a calibrated model to predict depths and velocities at unmeasured discharges.

Two-dimensional hydrodynamic model - a kind of open channel flow model that solves the forces acting on a vertical column of water to produce maps of depth and velocity over a section of river.

\section{Responses to the eight standardized questions from the Governor's Upper Yellowstone River Task Force}

1. Recognizing your study's budget and time constraints, how comprehensive are your data relative to the Task Force study area of the Yellowstone River?

Study areas were selected to: (1) represent the geomorphic setting where channel modification occurred or was likely to occur; (2) include a range of intensity of channel modification; and (3) coincide with study reaches sampled during the fish population study. The range of conditions included in the study reaches is representative of conditions in other wandering, gravel-bed sections of the Yellowstone River.

2. Have you found significant differences in your results relative to different geomorphic sub-reaches of the Task Force study area of the Yellowstone River? Why? Why not?

The fish habitat study focused on the wandering gravel-bed channel type that is represented in the Yellowstone River near Livingston, MT. We did not collect data in dramatically different geomorphic settings. Among the reaches studied we found that the Livingston reach had the largest percentage area affected by channel modification and the 
smallest area of SSCV habitat during a typical bankfull flow. At the Livingston site there was less SSCV habitat available in side channel and overbank areas during bankfull discharge compared to the other study sites.

3. How important is the connectivity between the floodplain and river in the interpretation of your data?

Our study focused on the availability and spatial distribution of shallow, slow current velocity (SSCV) habitat that is used by juvenile fishes. Habitat modeling results showed that side channel and floodplain (overbank) areas provided an average of $84 \%$ of the total amount of SSCV habitat available at bankfull discharge. During the runoff period young fish are most vulnerable to downstream displacement. Floodplains and ephemeral side channels provide important refugia for juvenile fish during high flows. Without connectivity, the amount of SSCV habitat would be lower in the reaches studied. This would probably result in local reductions in juvenile fish abundances during bankfull discharge.

4. How have the resources you studied in the Upper Yellowstone River changed over the last 50 to 300 years?

Based on permit numbers, historical photos, and the availability of efficient earth moving equipment, we suspect the majority of significant channel modification in the areas studied occurred during the last 50 years. This implies that most changes in fish habitat availability tied to channel modification would have occurred since the 1950's. The primary fish species of interest include rainbow trout and brown trout which were introduced about 100 years ago. Based on settlement dates for Livingston, it is likely that between 300 and 100 years ago there was virtually no channel modification that would influence fish habitat. It is important to note that the river channel could still be responding to channel modifications that occurred during the 1950's and is likely to be still responding to more recent modifications.

5. Are there any particular river conditions-natural or anthropogenic-that your results indicate are important stressors on the river processes that you studied?

The fish habitat study demonstrated the importance of side channel and overbank areas as habitat for young fish during periods of high discharge. Results also suggest that channel confinement reduces the availability of shallow, slow current velocity habitats. Channel modification structures are used to prevent erosion or floodplain inundation. If structures are effective they can reduce the rate of channel migration or prevent flooding. Channel migration and floodplain inundation are both essential processes for the functioning of alluvial floodplain rivers. These processes maintain the habitats that support fish (and wildlife) populations.

6. Recognizing the short-term nature of your study, do you think that the condition of Upper Yellowstone River Watershed-for example, its vegetation cover, recent drought, altering events such as fires, timber cutting, grazing, and residential 
development-have influenced your research results, relative to the river processes you studied?

Probably the most important factor affecting our results was the interaction between runoff and channel modification that has occurred during recent times to produce the channel configuration we see today. For example, if a major flood had occurred in 2001, rather than drought, our maps would have looked somewhat different. The mapping and modeling work done as part of this study is built on topographic survey, hydrographic survey, and remotely sensed data. The topography of the river and river valley are constantly changing in response to both natural and human-induced forces. The results of this study represent a snapshot of conditions that were present when survey data were collected.

7. What portion of your results do you see integrating with results of other Task Force studies?

Our work integrates directly with the results from the fish population study. The analyses of the habitat study were designed to address important questions raised by the fish population study. Our work also benefited from data and analysis provided by the hydrology and geomorphology studies. Maps of flood extent from the hydrology study will be used to evaluate shallow water habitat availability for the entire area covered by the flood mapping work. Results from the fish habitat study will be used by investigators conducting the geomorphology study.

\section{What other questions were raised by your research?}

What is the pattern of habitat use by juvenile fish from runoff through flow recession? How do juvenile fish growth and survival in side channel or backwater habitats compare with main channel habitats? How important to local fish recruitment in disturbed areas are longitudinal connections to undisturbed areas? Is there a critical (threshold) distance between recruitment sources, beyond which reductions in adult populations will occur? Can we identify thresholds where modification and channel confinement will disrupt processes that support formation and maintenance of important habitats? Can we identify critical floodway widths in different geomorphic settings that would allow the river to maintain important habitats? Is there a statistically significant relation between criticalperiod SSCV and year-class strength in the upper Yellowstone River? Is the trout population of the upper Yellowstone recruitment-limited? 